\title{
Superior creep resistance of a high-Cr steel with Re additives
}

\author{
A. Fedoseeva ${ }^{\text {a,* }}$, I. Nikitin ${ }^{\text {a }}$, N. Dudova ${ }^{a}$, R. Kaibyshev ${ }^{\text {a }}$ \\ ${ }^{a}$ Belgorod National Research University, Belgorod 308015, Russia
}

\section{A R T I C L E I N F O}

\section{Article history:}

Received 15 October 2019

Received in revised form 10 December 2019

Accepted 14 December 2019

Available online 16 December 2019

\section{Keywords:}

Metals and alloys

Creep

Electron microscopy

Microstructure

Particles

Diffusion

\begin{abstract}
A B S T R A C T
Re-containing $10 \mathrm{Cr}-3 \mathrm{Co}-3 \mathrm{~W}$ martensitic steel with low nitrogen and high boron contents exhibited a rupture time of $10,987 \mathrm{~h}$ at $650^{\circ} \mathrm{C} / 140 \mathrm{MPa}$. This superior creep resistance was caused by partially saved tempered martensite lath structure due to precipitation of $\mathrm{M}_{23} \mathrm{C}_{6}$ carbides and Laves phase chains on lath boundaries as well as their high resistance to coarsening. $\mathrm{M}_{23} \mathrm{C}_{6}$ carbides were characterized by decreased interfacial energy that resulted in the retention of the orientation relationship between $\mathrm{M}_{23} \mathrm{C}_{6}$ carbides and ferritic matrix. Re slowed down diffusion of $\mathrm{W}$, Mo and $\mathrm{Cr}$ atoms.
\end{abstract}

(c) 2019 Elsevier B.V. All rights reserved.

\section{Introduction}

Creep resistant $9-12 \% \mathrm{Cr}$ martensitic steels are widely used as materials for fossil power plants [1-2]. New generation of the 9$12 \% \mathrm{Cr}-3 \%$ Co martensitic steels with low $\mathrm{N}$ and high $\mathrm{B}$ contents demonstrates enhanced creep resistance up to $650{ }^{\circ} \mathrm{C}$ because of the combination of strengthening effects from the lath structure, high dislocation density, supersaturated solid solution and precipitation of the $\mathrm{M}_{23}(\mathrm{C}, \mathrm{B})_{6}$ phase and Laves phase [3-17]. These dispersoids provide stability of tempered martensite lath structure (TMLS) under creep and contribute to dispersion strengthening exerting high threshold stress [3,14]. Dudova et al. [14] indicated the creep strength of the $10 \% \mathrm{Cr}$ steel with low $\mathrm{N}$ and high $\mathrm{B}$ contents approaches $100 \mathrm{MPa}$ for $100,000 \mathrm{~h}$ at $650{ }^{\circ} \mathrm{C}$. Re additives to this $10 \% \mathrm{Cr}$ steel provide additional improvement of its creep strength [16-18]. Re slows down diffusion rate [1,18]. Re atoms should contribute to stable dislocation substructure [16]. However, the exact origin of excellent creep resistance of Recontaining high- $\mathrm{Cr}$ martensitic steel is poorly known [16-18]. The aim of the present work is to consider microstructural aspects of improved creep resistance of a martensitic $10 \mathrm{Cr}-3 \mathrm{Co}-3 \mathrm{~W}-0.2 \mathrm{Re}$ steel under creep condition of $650{ }^{\circ} \mathrm{C} / 140 \mathrm{MPa}$ in comparison with the Re-free steel, which is denoted here as $10 \mathrm{Cr}-3 \mathrm{Co}-2 \mathrm{~W}-0 \mathrm{Re}$ $[3,12,14,15]$.

\footnotetext{
* Corresponding author.

E-mail address: fedoseeva@bsu.edu.ru (A. Fedoseeva).
}

\section{Material and experimental}

A Re-containing steel, which is denoted here as $10 \mathrm{Cr}-3 \mathrm{Co}-3 \mathrm{~W}-$ $0.2 \mathrm{Re}$, was prepared by vacuum induction melting as $100 \mathrm{~kg}$ ingot. The steel was homogenized at $1150{ }^{\circ} \mathrm{C}$ and forged at $1150-950{ }^{\circ} \mathrm{C}$. Chemical composition and heat treatment of this steel are listed in Table 1. The $10 \mathrm{Cr}-3 \mathrm{Co}-3 \mathrm{~W}-0.2 \mathrm{Re}$ steel was solution treated at $1050{ }^{\circ} \mathrm{C}$ for $1 \mathrm{~h}$, cooled in air, and tempered at $770{ }^{\circ} \mathrm{C}$ for $3 \mathrm{~h}$. Flat specimens with a gauge length of $25 \mathrm{~mm}$ and a cross section of $7 \mathrm{~mm} \times 3 \mathrm{~mm}$ were crept until rupture at $650^{\circ} \mathrm{C}$ under the applied stresses of 140-200 MPa. The structural characterization was carried out using a transmission electron microscope JEOL-2100 (TEM) and scanning electron microscopy Quanta 600 3D (SEM) on ruptured creep specimens. The TEM specimens were prepared by electropolishing at room temperature using Struers «Tenupol5» machine. The precipitates were identified from both the chemical analysis and the selected-area diffraction method on at least 200 particles. Other details of mechanical and structural characterization were reported in $[3,8,9,13-15,17]$. Analysis of $\dot{\varepsilon}$ vs $\varepsilon$ curves was performed by techniques described in $[3,19]$.

\section{Results and discussion}

Normalizing followed by tempering (Table 1 ) produced TMLS with a high dislocation density of $\sim 2 \times 10^{14} \mathrm{~m}^{-2}$ within laths with a thickness of $300-400 \mathrm{~nm}$ in both steels [3,12,14,15,17]. Cr-rich $\mathrm{M}_{23} \mathrm{C}_{6}$ carbides with a mean size ranging from 60 to $70 \mathrm{~nm}$ precipitated on boundaries of prior austenite grain (PAG), packets, blocks and martensitic laths. The feature of the $10 \mathrm{Cr}-3 \mathrm{Co}-3 \mathrm{~W}-0.2 \mathrm{Re}$ steel 
Table 1

Chemical compositions of the steels studied (in wt.\%) and their heat treatments.

\begin{tabular}{|c|c|c|c|c|c|c|c|c|c|c|}
\hline Steel & $C$ & $\mathrm{Cr}$ & $\mathrm{Co}$ & Mo & $\mathrm{W}$ & $\mathrm{V}$ & $\mathrm{Nb}$ & B & $\mathrm{N}$ & $\mathrm{Re}$ \\
\hline $10 \mathrm{Cr}-3 \mathrm{Co}-3 \mathrm{~W}-0.2 \mathrm{Re}$ & 0.11 & 9.85 & 3.2 & 0.13 & 3.2 & 0.2 & 0.07 & 0.008 & 0.002 & 0.17 \\
\hline Re-free $10 \mathrm{Cr}-3 \mathrm{Co}-3 \mathrm{~W}-0 \mathrm{Re}$ & 0.10 & 10.0 & 3.0 & 0.70 & 2.0 & 0.2 & 0.05 & 0.008 & 0.003 & - \\
\hline
\end{tabular}

HT: Normalization at $1050-1060{ }^{\circ} \mathrm{C}$ for $1 \mathrm{~h}$, air cooling, and tempering at $770{ }^{\circ} \mathrm{C}$ for $3 \mathrm{~h}$
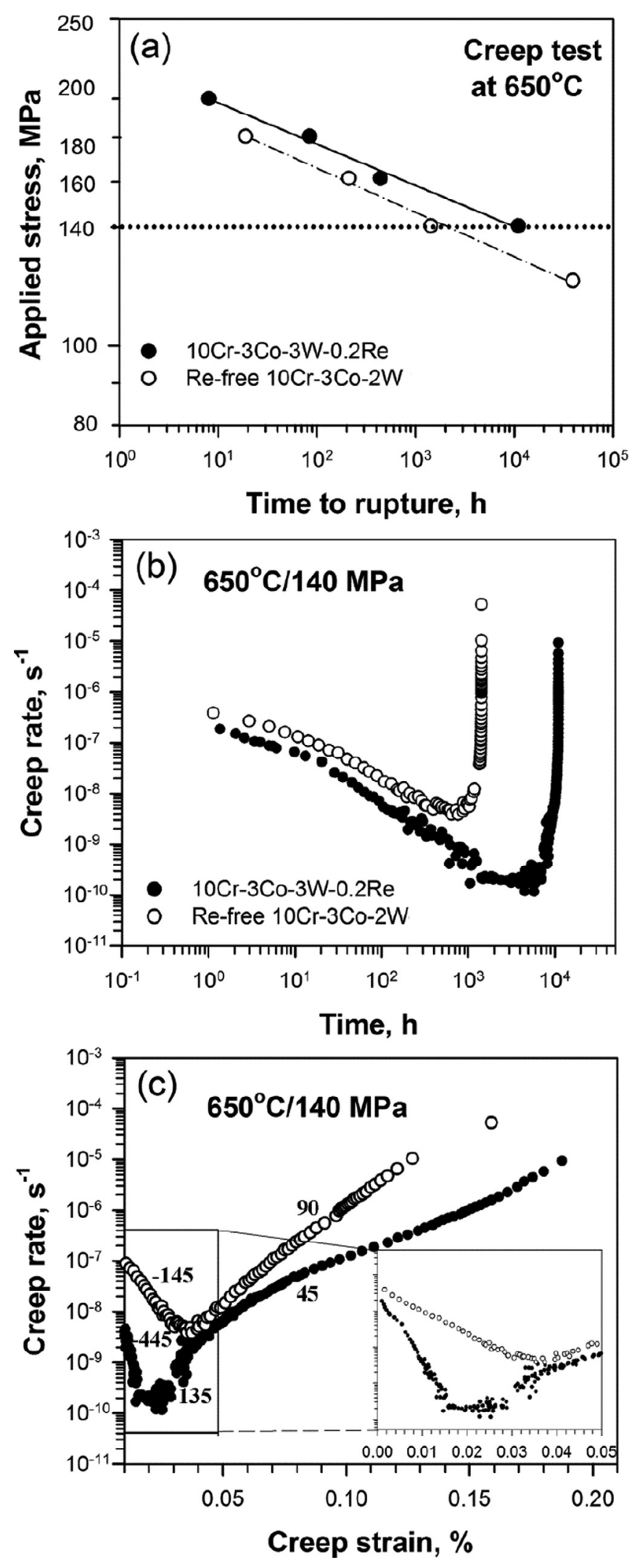

is high density of $\mathrm{M}_{23} \mathrm{C}_{6}$ carbides on lath boundaries. Nb-rich MX carbonitrides with a mean size ranging from 30 to $40 \mathrm{~nm}$ randomly distributed in the ferritic matrix in both steels. On the other hand, the $10 \mathrm{Cr}-3 \mathrm{Co}-3 \mathrm{~W}-0.2 \mathrm{Re}$ steel had $+70 \%$ larger PAG size $(59 \mu \mathrm{m})$ [17] as compared to the $10 \mathrm{Cr}-3 \mathrm{Co}-2 \mathrm{~W}-0 \mathrm{Re}$ steel $(35 \mu \mathrm{m})$ $[3,12,14,15]$.

Two steels exhibited a linear dependence of applied stress on rupture time (Fig. 1a). Such alloying distinctions of the Recontaining steel as the $0.2 \%$ Re additives, $+1 \%$ increase in $\mathrm{W}$ content and $-0.4 \%$ decrease in Mo content provided 4.6, 2.1 and 7.7 time increases in rupture times at 180,160 and $140 \mathrm{MPa}$, respectively. Inspection of the $\dot{\varepsilon}$ vs $t$ and $\dot{\varepsilon}$ vs $\varepsilon$ curves (Fig. 1b and c) showed that at $650{ }^{\circ} \mathrm{C} / 140 \mathrm{MPa}$, the Re-containing steel exhibited the minimum creep rate, $\dot{\varepsilon}_{\text {min }}$, at $2 \times 10^{-10} \mathrm{~s}^{-1}$ that was 20 times lower than that in the $10 \mathrm{Cr}-3 \mathrm{Co}-2 \mathrm{~W}$-0Re steel $\left(\sim 4 \times 10^{-9} \mathrm{~s}^{-1}\right)$ [15]. In addition, time to minimum creep rate shifted up to $8,000 \mathrm{~h}$ for the $\mathrm{Re}$ containing steel instead of $700 \mathrm{~h}$ for the Re-free steel and the offset strain, at which the minimum creep rate is attained, decreased to $1.8 \%$ instead of $3.5 \%$ (Fig. $1 \mathrm{~b}$ and c). Elongation to rupture was similar for both steels (Fig. 1c).

Under the transient creep, magnitude of strain rate dropped by a factor of $\sim 10$ due to a strong increase in the parameterdln $\dot{\varepsilon} / d \varepsilon \sim-$ 445 , which was higher by a factor of $\sim 3$ than that of the Re-free steel [15] (Fig. 1c). Thedln $\dot{\varepsilon} / d \varepsilon \sim-445$ is close to the rate of kinetic reactions in the Re-free steel at $120 \mathrm{MPa}$, at which a superior rupture time of $\sim 40,000 \mathrm{~h}$ was attained [3]. The Re-containing steel exhibited unusual tertiary creep behavior with two distinct stages. The $d \ln \dot{\varepsilon} / d \varepsilon v a l u e s$ of $\sim 135$ and $\sim 45$ were calculated for first stage from $\dot{\varepsilon}_{\min }$ to $5 \%$ and second stage from 5\% to rupture, respectively (Fig. 1c). Therefore, the rate of acceleration of tertiary creep decreased with increasing time/strain.

After creep test at $650{ }^{\circ} \mathrm{C} / 140 \mathrm{MPa}$, TMLS of the $10 \mathrm{Cr}-3 \mathrm{Co}-3 \mathrm{~W}$ 0.2 Re steel was partially transformed into the subgrain structure with a mean subgrain size of $1.1 \mu \mathrm{m}$ (Fig. 2a, b). Dislocation density decreased to $1.7 \times 10^{13} \mathrm{~m}^{-2}$. It was recently shown [17] that $\mathrm{W}$ content in the ferritic matrix approached $1.24 \mathrm{wt} \%$ in both steels after $500 \mathrm{~h}$ of creep; all differences between the crept structures in the Re-containing and Re-free steels after $500 \mathrm{~h}$ of creep can be related only to Re additives. The constant growth rate $\mathrm{Kg}$ of subgrains was $4.29 \times 10^{-8} \mu^{3} \mathrm{~s}^{-1}$ (Fig. 2c) for the 10Cr-3Co-3W-0.2Re steel that was similar with that of the $10 \mathrm{Cr}-3 \mathrm{Co}-2 \mathrm{~W}$-0Re steel. Extensive coarsening of $\mathrm{M}_{23} \mathrm{C}_{6}$ carbides located on boundaries of PAG and packets increased their size up to $120 \mathrm{~nm}$ (Fig. 2a and b), while some $\mathrm{M}_{23} \mathrm{C}_{6}$ carbides located on lath boundaries retained size ranging from 50 to $70 \mathrm{~nm}$ (Fig. 3). The constant growth rate $\mathrm{Kg}$ of $\mathrm{M}_{23} \mathrm{C}_{6}$ carbides was $4.49 \times 10^{-12} \mu^{4} \mathrm{~s}^{-1}$ (Fig. $2 \mathrm{~d}$ ) for the $10 \mathrm{Cr}-3 \mathrm{Co}-3 \mathrm{~W}$ 0.2 Re steel that was significantly lower than that of the Re-free steel. The decrease in the constant growth rate $\mathrm{Kg}$ of $\mathrm{M}_{23} \mathrm{C}_{6}$ carbide was described by a 2 -fold decrease in the interfacial energy from $0.1 \mathrm{~J} \mathrm{~m}^{-2}$ for the $10 \mathrm{Cr}-3 \mathrm{Co}-2 \mathrm{~W}-0$ Re steel [15] to $0.05 \mathrm{~J} \mathrm{~m}^{-2}$ for the 10Cr-3Co-3W-0.2Re steel (Fig. 3g). Fine $\mathrm{M}_{23} \mathrm{C}_{6}$ particles located on

Fig. 1. Creep behavior of the $10 \mathrm{Cr}-3 \mathrm{Co}-3 \mathrm{~W}-0.2 \mathrm{Re}$ steel: applied stress vs. time to rupture (a), creep rate vs. time (b) and creep rate vs. strain (c) in comparison with the Re-free steel [15]. 

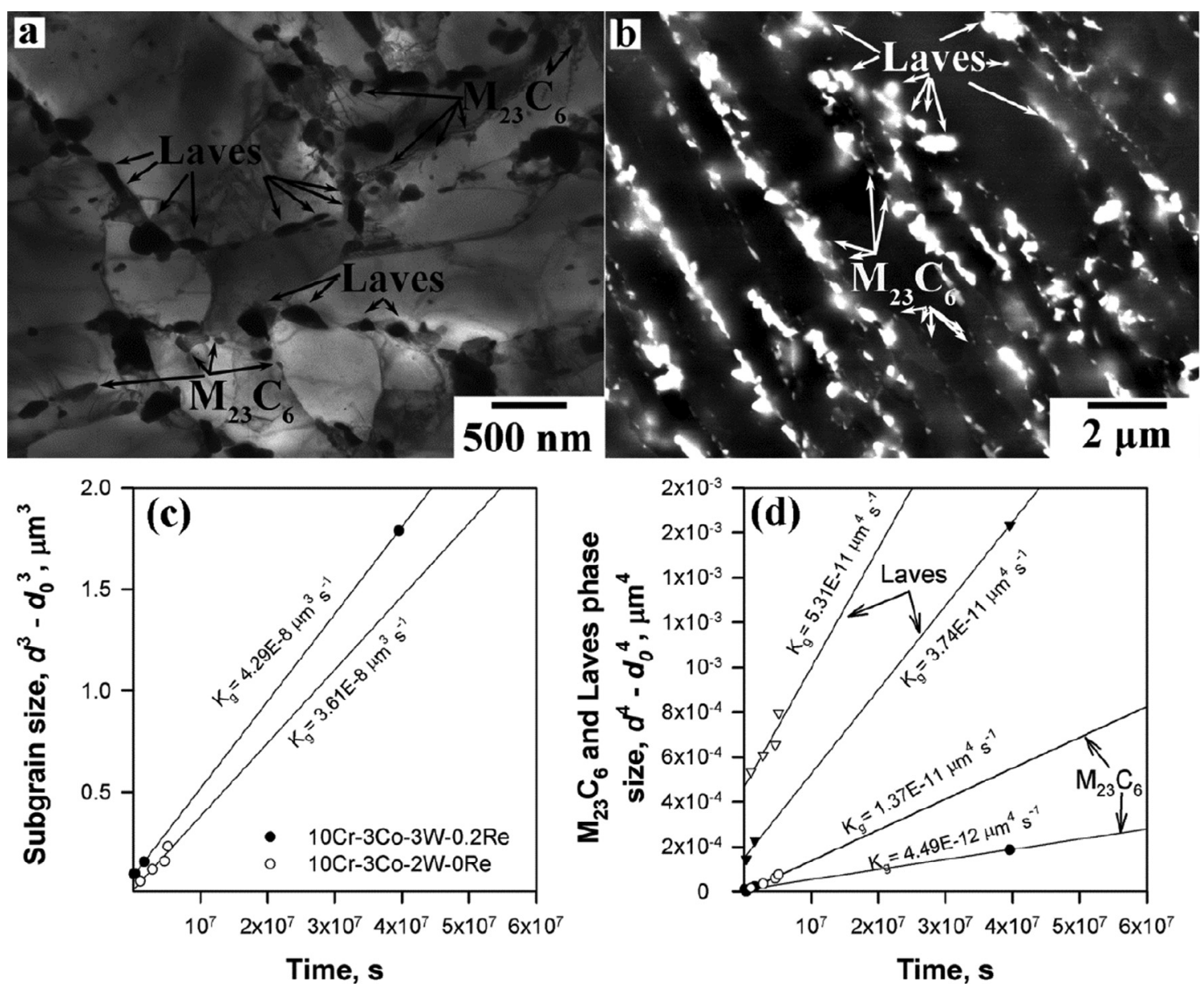

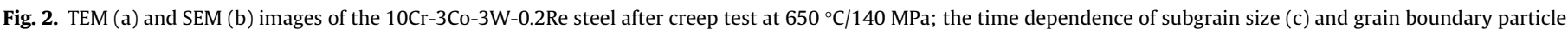
size (d) in comparison with the Re-free steel [15]. Numbers indicate the coarsening rate constant.

low-angle boundaries retained their orientation relationships (OR) with ferritic matrix, such as Kurdjumov-Sachs OR: $(1 \overline{1} 0)_{\alpha-F e}\left\|(111)_{M 23 C 6},[11 \overline{1}]_{\alpha-F e}\right\|[01 \overline{1}]_{M 23 C 6}$ with lattice misfit 1.1\% (Fig. $3 \mathrm{a}$ ), $\quad$ Pitsch $(\overline{121})_{\alpha-F e}\left\|(660)_{M 23 C 6},[11 \overline{1}]_{\alpha-F e}\right\|[3 \overline{3} 2]_{M 23 C 6}$ with lattice misfit $7.3 \%$ (Fig. 3c), $(\overline{101})_{\alpha-F e}\left\|(600)_{M 23 C 6},[1 \overline{3} 1]_{\alpha-F e}\right\|[0 \overline{1} 5]_{M 23 C 6}$ with lattice misfit $12.4 \%$ (Fig. 3d).

Laves phase precipitated along boundaries after $110 \mathrm{~h}$ of creep/ aging. Most of Laves phase particles precipitated on lath boundaries retained OR with ferritic matrix of $\left(\begin{array}{lll}\overline{1} & \overline{1} & \overline{2}\end{array}\right)_{\alpha-F e}\left\|(302)_{\text {Laves }}, \quad\left[\begin{array}{lll}1 & \overline{3} & 1\end{array}\right]_{\alpha-F e}\right\|\left[\begin{array}{lll}0 & \overline{1} & 0\end{array}\right]_{\text {Laves }}$ with lattice misfit $10.3 \%$ even after $10,987 \mathrm{~h}$ of creep (Fig. 3f). These particles were smaller than those decorated boundaries of PAGs and packets (Figs. 2b, 3e). The constant growth rate $\mathrm{Kg}$ of $3.74 \times 10^{-11} \mu \mathrm{m}^{4}$ $\mathrm{s}^{-1}$ (Fig. 2d) was insignificantly lower than that of the Re-free steel. The interfacial energy of Laves phase in the $10 \mathrm{Cr}-3 \mathrm{Co}-3 \mathrm{~W}-0.2 \mathrm{Re}$ steel was higher than that of Re-free $10 \mathrm{Cr}-3 \mathrm{Co}-2 \mathrm{~W}-0 \mathrm{Re}$ steel; however, this did not lead to a significant increase in its constant growth rate. This fact indicates that Re additives slow down the diffusion of Fe and alloying elements such as W, Mo and $\mathrm{Cr}$ comprising the Laves phase according to $[13,18]$.

The coherency of $\mathrm{M}_{23} \mathrm{C}_{6}$ carbides and Laves phase particles precipitated heterogeneously provides retention of chains of these particles on lath boundaries after rupture that is quite unusual. In contrast with the other high-Cr steels $[1,8,13,15]$, Re additives, which provide coherency of boundary particle interfaces and slowing down diffusion rate, prevent dissolution of the fine particle chains along lath boundaries under creep. These chains stabilize TMLS during 10,987 h of creep under the high applied stress.

\section{Conclusions}

At $650{ }^{\circ} \mathrm{C}$ and an applied stress of $140 \mathrm{MPa}$, Re additions in the high-Cr steel with low $\mathrm{N}$ and high $\mathrm{B}$ contents increase creep rupture time by a factor of $\sim 8$ due to the formation of dense precipitations of $\mathrm{M}_{23} \mathrm{C}_{6}$ carbides and Laves phase on lath boundaries that leads to strong hardening under transient creep, low $\dot{\varepsilon}_{\text {min }}$ value and extended steady-state creep stage. These additions decreased the energy of $\mathrm{M}_{23} \mathrm{C}_{6}$ /ferrite interfaces and induced nucleation of Laves phase with coherent interfaces. Re also slows down diffusion. As a result, coarsening of $\mathrm{M}_{23} \mathrm{C}_{6}$ carbides and Laves phase occurred with low rates; the chains of these particles on lath boundaries retained up to rupture. Superposition of these factors provided superior creep resistance of Re-containing steel.

Alexandra Fedoseeva, Nadezhda Dudova and Rustam Kaibyshev formulated the original problem, designed the study, developed the methodology and wrote the manuscript. Ivan Nikitin carried out creep tests, collected data and assisted with data analysis. Alexandra Fedoseeva and Nadezhda Dudova performed the TEM investigations, collected data and provided interpretation of data. Rustam Kaibyshev provided direction, guidance and interpretation of data. 

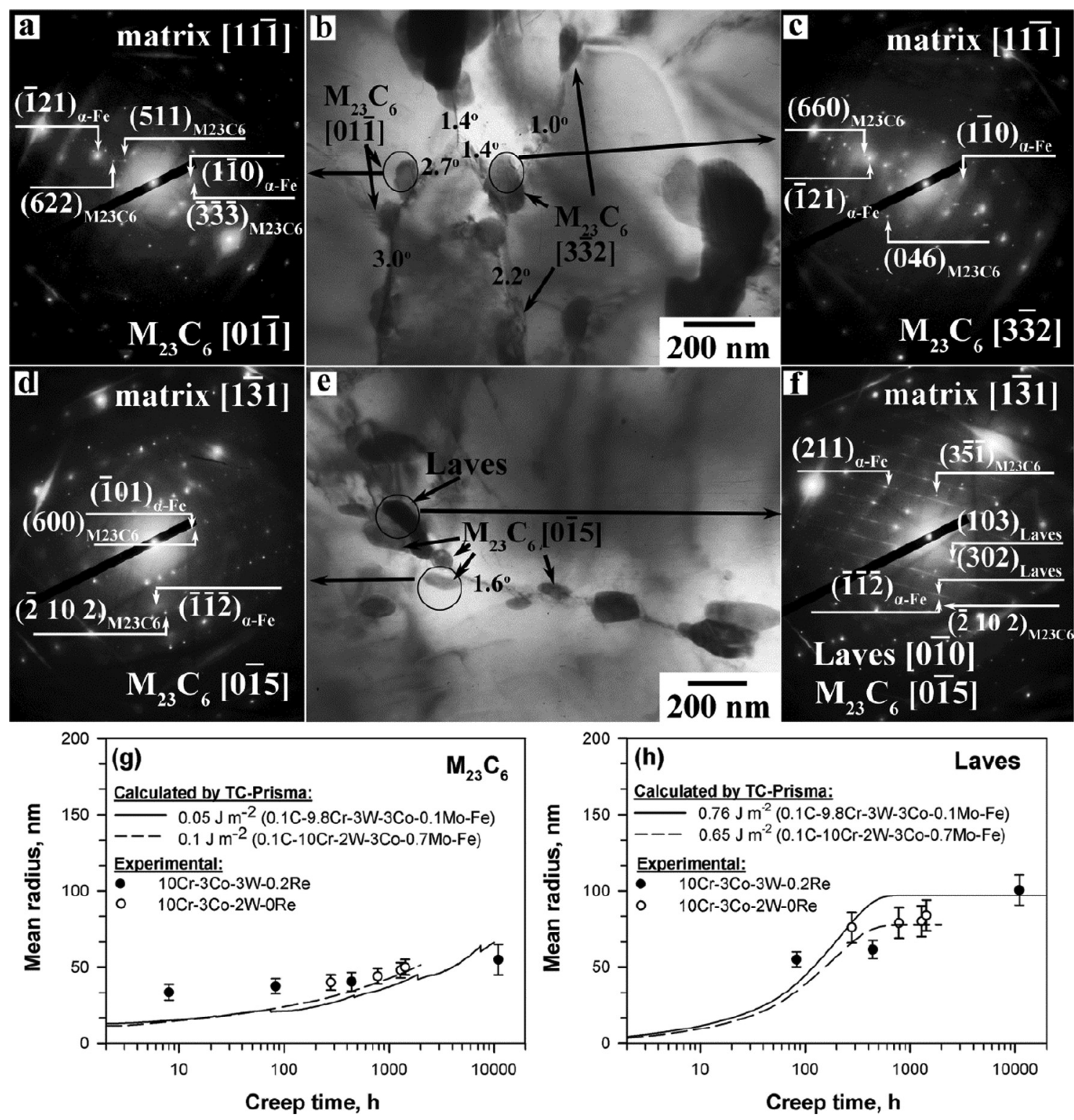

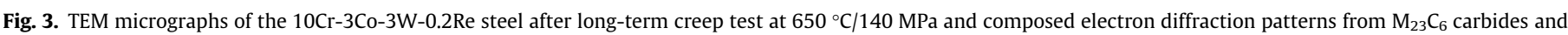

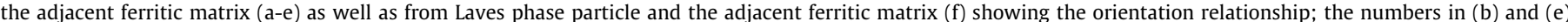

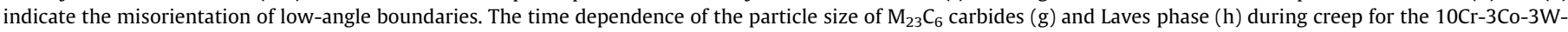
$0.2 \mathrm{Re}$ and Re-free steels.

\section{Declaration of Competing Interest}

The authors declare that they have no known competing financial interests or personal relationships that could have appeared to influence the work reported in this paper.

\section{Acknowledgments}

This study was financially supported by the Russian Science Foundation, under grant No. 19-73-10089.

\section{References}

[1] F. Abe, T.U. Kern, R. Viswanathan, Creep resistant steels, Woodhead Publishing, Cambridge, England, 2008.

[2] T.-U. Kern, M. Staubli, B. Scarlin, ISIJ International 42 (2002) 1515-1519.

[3] R. Mishnev, N. Dudova, R. Kaibyshev, Mater. Sci. Eng. A 713 (2018) 161-173.

[4] A. Kostka, K.-G. Tak, R.J. Hellmig, Y. Estrin, G. Eggeler, Acta Mater. 55 (2007) 539-550.

[5] F. Abe, Metal. Mater. Trans. A 36 (2005) 321-331.
[6] O. Prat, J. Garcia, D. Rojas, G. Sauthoff, G. Inden, Intermetallics 32 (2013) 362 372.

[7] M.I. Isik, A. Kostka, V.A. Yardley, K.G. Pradeep, M.J. Duarte, P.P. Choi, D. Raabe, G. Eggeler, Acta Mater. 90 (2015) 94-104.

[8] I. Fedorova, A. Belyakov, P. Kozlov, V. Skorobogatykh, I. Shenkova, R. Kaibyshev, Mater. Sci. Eng. A 615 (2014) 153-163.

[9] A. Fedoseeva, N. Dudova, R. Kaibyshev, Trans. Ind. Inst. Met. 69 (2016) 211 215.

[10] R. Sahara, T. Matsunaga, H. Hongo, M. Tabuchi, Metall. Mater. Trans. A 47 (2016) 1-11.

[11] Y. Liu, S. Tsukamoto, K. Sawada, M. Tabuchi, F. Abe, Metall. Mater. Trans. A 46 (2015) 1843-1854.

[12] N. Dudova, R. Kaibyshev, ISIJ Int. 51 (2011) 826-831.

[13] A. Fedoseeva, E. Tkachev, V. Dudko, N. Dudova, R. Kaibyshev, J. Mater. Sci. 52 (2017) 4197-4209.

[14] N. Dudova, R. Mishnev, R. Kaibyshev, Mater. Sci. Eng. A 766 (2019) 138353.

[15] R. Mishnev, N. Dudova, A. Fedoseeva, R. Kaibyshev, Mater. Sci. Eng. A 678 (2016) 178-189.

[16] K. Maruyama, K. Sawada, J. Koike, ISIJ International 41 (2001) 641-653.

[17] A. Fedoseeva, I. Nikitin, N. Dudova, R. Kaibyshev, Mater. Lett. 236 (2019) 8184.

[18] R. Hashizume et al., Tetsu-to-Hagane 95 (2009) 176-185.

[19] F. Abe, Metall. Mater. Trans. A 46 (2015) 5610-5625. 